\title{
LEUKOKINETIC STUDIES. IV. THE TOTAL BLOOD, CIRCULATING AND MARGINAL GRANULOCYTE POOLS AND THE GRANULOCYTE TURNOVER RATE IN NORMAL SUBJECTS *
}

By J. W. ATHENS, O. P. HAAB, $\dagger$ S. O. RAAB, A. M. MAUER $\ddagger$ H. ASHENBRUCKER, G. E. CARTWRIGHT AND M. M. WINTROBE

(From the Department of Medicine, University of Utah College of Medicine, Salt Lake City, Utah)

(Submitted for publication January 19, 1961 ; accepted February 17, 1961)

When granulocytes are labeled with diisopropylfluorophosphate $\left(\mathrm{DFP}^{32}\right)$ and then returned to the circulation of the donor, the labeled granulocytes are distributed in a pool of cells which is approximately two times larger than that calculated from the blood volume and the concentration of granulocytes in the circulating venous blood $(1,2)$. This pool has been referred to as the total blood granulocyte pool (TBGP) and it consists of two subcompartments or pools. These pools have been designated the circulating granulocyte pool (CGP) and the marginal granulocyte pool (MGP). The size of the CGP can be calculated from the blood volume and the absolute granulocyte count. Equilibration between the granulocytes in the CGP and in the "noncirculating" or MGP is sufficiently rapid and complete to allow these two pools to be considered as one kinetically, and the size of the TBGP can be determined by the isotope dilution principle. Since the cells are removed from the TBGP in an exponential fashion with a mean half-time disappearance $\left(\mathrm{T}_{\frac{1}{2}}\right)$ of 6.6 hours, the granulocyte turnover rate (GTR), that is, the number of granulocytes turned over through the blood in a unit of time, can be calculated.

The purpose of this paper is to present data on the GTR in normal subjects, as well as additional data on the size of the TBGP, CGP and MGP in normal subjects. The influence of steroids, physical exercise, epinephrine and bacterial endotoxin on these parameters in normal subjects has also been studied.

* This investigation was supported by a research grant (A-4489) and a graduate training grant (2A-5098) from the National Institute of Arthritis and Metabolic Diseases, Bethesda, Md.

$\dagger$ Fellow of the Leukemia Society, Inc., New York, N. Y.

$\$$ American Cancer Society Postdoctoral Fellow.
Several preliminary reports of this work have been published $(3,4)$.

\section{MATERIALS AND METHODS}

Twenty-five volunteers from the Utah State Prison, in addition to the 45 subjects previously reported $(1,2)$, were used in these studies. All of the subjects were normal healthy males, 20 to 50 years of age, with normal leukocyte values. The subjects ate breakfast at 6:00 a.m. and the infusion of labeled blood was begun between 8:00 and 10:00 a.m.

The methods for labeling blood in vitro, for the isolation of leukocytes from the blood samples, for the determination of leukocyte radioactivity, and for the calculation of the TBGP, CGP and $T_{2}$ have been described in previous publications $(1,2,5)$.

The GTR, defined as the number of granulocytes turned over through the blood each day per kilogram body weight, was calculated from the following equation (6) : GTR $=24 \times 0.693 / \mathrm{T}_{\frac{1}{2}}(\mathrm{hrs}) \times \mathrm{TBGP}$ (no. cells $\left.\times 10^{7} / \mathrm{kg}\right)$.

The $\mathrm{DFP}^{32}$ was purchased from the New England Nuclear Corp., Boston, Mass., as a dilute solution $(1.0 \mathrm{mg}$ per $\mathrm{ml}$ ) in sterile, anhydrous propylene glycol. The concentration of DFP was determined in our own laboratory by a modification of the method of Marsh and Neale (7). The specific activity of the material at the time it was used was 74 to $224 \mu \mathrm{c}$ per mg. Except when noted otherwise, $\mathrm{DFP}^{32}$ was added to the blood (400 to 500 $\mathrm{ml}$ ) in the bag in a concentration of $0.3 \mu \mathrm{g}$ per $\mathrm{ml}$ of whole blood.

\section{RESULTS}

$T B G P, C G P, M G P, T_{1}$ and $G T R$ in normal subjects. The values for the total blood granulocyte pool, circulating granulocyte pool, marginal granulocyte pool, half-time disappearance and granulocyte turnover rate in normal male subjects are presented in Table I. The pool sizes were determined on a total of 70 normal subjects, including the 45 subjects previously reported (2). The $T_{1}$ and GTR were determined on 45 of the 70 individuals. 
TABLE I

The total blood granulocyte pool (TBGP), circulating granulocyte pool (CGP), marginal granulocyte pool ( $M G P)$ half-time disappearance $\left(T_{\frac{1}{3}}\right)$ and granulocyte turnover rate (GTR) in normal male subjects

\begin{tabular}{lccc}
\hline \hline \multicolumn{1}{c}{ Determination } & Mean & $\pm 1 \mathrm{SD}^{*}$ & $\begin{array}{c}\text { Determined } \\
\text { range }\end{array}$ \\
\hline $\mathrm{TBGP} \times 10^{7} / \mathrm{kg}$ & 65.0 & 22.4 & $33-117$ \\
$\mathrm{CGP} \times 10^{7} / \mathrm{kg}$ & 31.7 & 11.1 & $15-54$ \\
$\mathrm{MGP} \times 10^{7} / \mathrm{kg}$ & 33.3 & 16.0 & $9-79$ \\
T & 6.6 & 1.16 & $4-9$ \\
GTR $\times 10^{7} / \mathrm{kg} /$ day & 179.9 & 74.3 & $86-341$ \\
\hline
\end{tabular}

* Standard deviation.

To determine the reproducibility of these parameters in normal subjects, studies were carried out in four subjects and repeated in the same subjects 1 month later. The concentration of $\mathrm{DFP}^{32}$ used was $0.15 \mu \mathrm{g}$ per $\mathrm{ml}$ of whole blood rather than the customary $0.30 \mu \mathrm{g}$ per $\mathrm{ml}$ so that the amount of radiation which each subject received was not increased. The results are presented in Table II.

TABLE II

The reproducibility of the measurement of the $T B G P, C G P, M G P, T_{\frac{1}{2}}$ and $G T R$ *

\begin{tabular}{|c|c|c|c|}
\hline Determination & $\begin{array}{c}\text { Subject } \\
\text { no. }\end{array}$ & $\begin{array}{c}\text { First } \\
\text { measure- } \\
\text { ment }\end{array}$ & $\begin{array}{c}\text { Second } \\
\text { measure- } \\
\text { ment }\end{array}$ \\
\hline $\mathrm{TBGP} \times 10^{7} / \mathrm{kg}$ & $\begin{array}{l}\text { IV-30 } \\
\text { IV-28 } \\
\text { IV-34 } \\
\text { IV-32 } \\
\text { Mean }\end{array}$ & $\begin{array}{l}91 \\
57 \\
66 \\
38 \\
63\end{array}$ & $\begin{array}{r}59 \\
106 \\
51 \\
53 \\
67\end{array}$ \\
\hline $\mathrm{CGP} \times 10^{7} / \mathrm{kg}$ & $\begin{array}{l}\text { IV-30 } \\
\text { IV-28 } \\
\text { IV-34 } \\
\text { IV-32 } \\
\text { Mean }\end{array}$ & $\begin{array}{l}45 \\
29 \\
26 \\
15 \\
29\end{array}$ & $\begin{array}{l}38 \\
33 \\
25 \\
19 \\
29\end{array}$ \\
\hline $\mathrm{MGP} \times 10^{7} / \mathrm{kg}$ & $\begin{array}{l}\text { IV-30 } \\
\text { IV-28 } \\
\text { IV-34 } \\
\text { IV-32 } \\
\text { Mean }\end{array}$ & $\begin{array}{l}46 \\
28 \\
40 \\
23 \\
34\end{array}$ & $\begin{array}{l}21 \\
73 \\
26 \\
34 \\
38\end{array}$ \\
\hline $\mathrm{T}_{\frac{1}{3}}(\mathrm{hrs})$ & $\begin{array}{l}\text { IV-30 } \\
\text { IV-28 } \\
\text { IV-34 } \\
\text { IV-32 } \\
\text { Mean }\end{array}$ & $\begin{array}{l}6.5 \\
6.6 \\
6.4 \\
7.4 \\
6.7\end{array}$ & $\begin{array}{l}8.5 \\
6.8 \\
5.0 \\
5.5 \\
6.5\end{array}$ \\
\hline GTR $\times 10^{7} / \mathrm{kg} /$ day & $\begin{array}{l}\text { IV-30 } \\
\text { IV-28 } \\
\text { IV-34 } \\
\text { IV-32 } \\
\text { Mean }\end{array}$ & $\begin{array}{r}231 \\
145 \\
170 \\
86 \\
158\end{array}$ & $\begin{array}{l}115 \\
259 \\
168 \\
160 \\
175\end{array}$ \\
\hline
\end{tabular}

* See Table I for abbreviations.
Influence of prednisone on the TBGP, CGP, $M G P, T_{1}$ and GTR. Each of five subjects was given an infusion of autogenous, $\mathrm{DFP}^{32}$-labeled blood $\left(0.15 \mu \mathrm{g}\right.$ of $\mathrm{DFP}^{32}$ per $\left.\mathrm{ml}\right)$. Control values for the TBGP, CGP, MGP, $T_{\frac{1}{2}}$ and GTR were obtained on each of the subjects. The subjects were then given $40 \mathrm{mg}$ of prednisone daily by the oral route for 11 days. The absolute granulocyte count increased an average of 75 per cent (35 to 120 ) by the eighth day and remained constant over the next 3 days. Measurements were repeated on the eighth day of steroid administration. The results are presented in Table III.

TABLE III

Influence of prednisone on the TBGP, CGP, MGP, $T_{\frac{1}{3}}$ and $G T R^{*}$

\begin{tabular}{ccc}
\hline \hline Determination & $\begin{array}{c}\text { Before } \\
\text { prednisone }\end{array}$ & $\begin{array}{c}\text { After } \\
\text { prednisone }\end{array}$ \\
\hline TBGP $\times 10^{7} / \mathrm{kg}$ & 48 & 80 \\
& $(37-55)$ & $(54-112)$ \\
$\mathrm{CGP} \times 10^{7} / \mathrm{kg}$ & 29 & 51 \\
$\mathrm{MGP} \times 10^{7} / \mathrm{kg}$ & $(18-45)$ & $(36-69)$ \\
& 19 & 29 \\
$\mathrm{~T}_{3}(\mathrm{hrs})$ & $(10-32)$ & $(18-43)$ \\
$\mathrm{GTR} \times 10^{7} / \mathrm{kg} /$ day & 119 & 10.3 \\
& $(85-142)$ & $(100-153)$
\end{tabular}

* The values represent the means of the determinations in 5 subjects. The figures in parentheses refer to range. See Table I for abbreviations.

Prednisone increased the CGP an average of 76 per cent, the MGP 53 per cent and the TBGP 67 per cent. In spite of this increase, the GTR was not altered significantly because of a prolongation of the $\mathrm{T}_{1}$.

Influence of exercise on the TBGP, CGP, MGP, $T_{1}$ and GTR. In a previous study (2) it was demonstrated that physical exercise resulted in a shift of granulocytes from the MGP to the CGP without an increase in the TBGP.

To determine if exercise influences the rate of disappearance of granulocytes from the blood, six subjects were given an infusion of autogenous, DFP $^{32}$-labeled blood. The pool sizes were determined and 6 hours later, at which time the slope of the disappearance curve was well established, the subjects ran 440 yards. In none of the sub- 
jects was the slope of the disappearance curve altered following exercise, in spite of the increase in the concentration of granulocytes in the CGP. The disappearance curve in a representative subject is presented in Figure 1.

Since exercise did not influence the slope of the disappearance curve, the GTR was calculated for each of the subjects. The data are summarized in Table IV. The values for the $T_{\frac{1}{2}}$ and for the GTR were within normal limits.

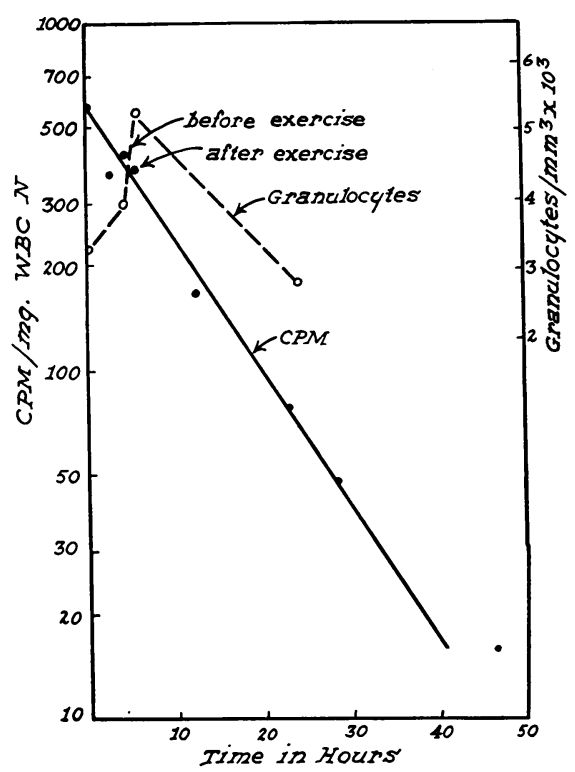

Fig. 1. Influence of exercise on the granulocyte DISAPPEARANCE CURVE AND ON THE CONCENTRATION OF GRANULOCYTES IN THE CIRCULATION. Six hours after the infusion of labeled blood, the subject ran 440 yards. The specific activity $(\mathrm{cpm} / \mathrm{mg}$ WBC $\mathrm{N})$ was the same immediately after exercise as before exercise, in spite of the increase in the granulocyte count. Thus, the cells which were mobilized into the CGP had the same specific activity as those already present in this pool. Furthermore, this shift of cells into the pool had no influence on the slope of the disappearance curve.

Influence of epinephrine on the TBGP, CGP, $M G P, T_{1}$ and $G T R$. In the previous publication (2), evidence was presented that epinephrine, like physical exercise, results in a shift of granulocytes from the MGP to the CGP, the TBGP remaining unchanged.

To determine if epinephrine influences the rate of disappearance of granulocytes from the blood, four subjects were given an infusion of autogenous, $\mathrm{DFP}^{32}$-labeled blood to which $0.5 \mathrm{mg}$ of epinephrine was added. The pool sizes and the $T_{\frac{1}{2}}$
TABLE IV

Influence of exercise and of epinephrine on the TBGP, CGP, $M G P, T$ and $G T R$ *

\begin{tabular}{ccc}
\hline \hline Determination & Exerciset & Epinephrinet \\
\hline TBGP $\times 10^{7} / \mathrm{kg}$ & 53 & 55 \\
$\mathrm{CGP} \times 10^{7} / \mathrm{kg}$ & $(40-85)$ & $(24-91)$ \\
& 46 & 35 \\
$\mathrm{MGP} \times 10^{7} / \mathrm{kg}$ & 7 & $(18-40)$ \\
& $(0-33)$ & $(6-52)$ \\
$\mathrm{T}_{5}^{5}(\mathrm{hrs})$ & 6.7 & 5.8 \\
$\mathrm{GTR} \times 10^{7} / \mathrm{kg} / \mathrm{day}$ & $(5.5-7.6)$ & $(4.6-7.6)$ \\
& $(102-214)$ & $(86-277)$
\end{tabular}

* See Table I for abbreviations.

+ Mean values for 6 subjects.

$\ddagger$ Mean values for 4 subjects. The figures in parentheses refer to range.

were then determined. The $\mathrm{T}_{\frac{1}{2}}$ and the GTR were within the normal limits in all four subjects (Table IV).

Influence of bacterial endotoxin on the TBGP, $C G P$ and $M G P$. The administration of bacterial endotoxin in small amounts to human subjects is associated with a granulocytosis 5 to 10 hours after the substance is given intravenously (8). A transient, mild granulocytopenia has been observed in some but not in all subjects 1 to 2 hours after the intravenous injection of endotoxin.

The influence of endotoxin (highly purified protein-free lipopolysaccharide from Salmonella abortus equi) on the TBGP, CGP and MGP was determined in six subjects. The pool sizes were measured on three separate occasions; before the intravenous administration of $0.1 \mu \mathrm{g}$ of bacterial

TABLE V

Influence of bacterial endotoxin on the TBGP, CGP and $M G P^{*}$

\begin{tabular}{lcccc}
\hline \hline Determination & $\begin{array}{c}\text { Before } \\
\text { endotoxin }\end{array}$ & \multicolumn{2}{c}{$\begin{array}{c}1.5 \mathrm{Hrs} \\
\text { after endotoxin }\end{array}$} & $\begin{array}{c}5.0 \mathrm{Hrs} \\
\text { after } \\
\text { endotoxin }\end{array}$ \\
\hline No. of subjects & 6 & 2 & 4 & 6 \\
TBGP $\times 10^{7} / \mathrm{kg}$ & 63 & 69 & 108 & 134 \\
& $(36-115)$ & $(49-89)$ & $(88-126)$ & $(111-146)$ \\
CGP $\times 10^{7} / \mathrm{kg}$ & 29 & 20 & 36 & 64 \\
MGP $\times 10^{7} / \mathrm{kg}$ & $(21-36)$ & $(13-28)$ & $(32-41)$ & $(51-95)$ \\
CGP $/ \mathrm{MGP}^{34}$ & $(9-79)$ & $(36-61)$ & $(56-85)$ & $(34-86)$ \\
& 0.86 & 0.41 & 0.50 & 0.91
\end{tabular}

* The figures in parentheses refer to range. See Table I for abbrevia tions. 


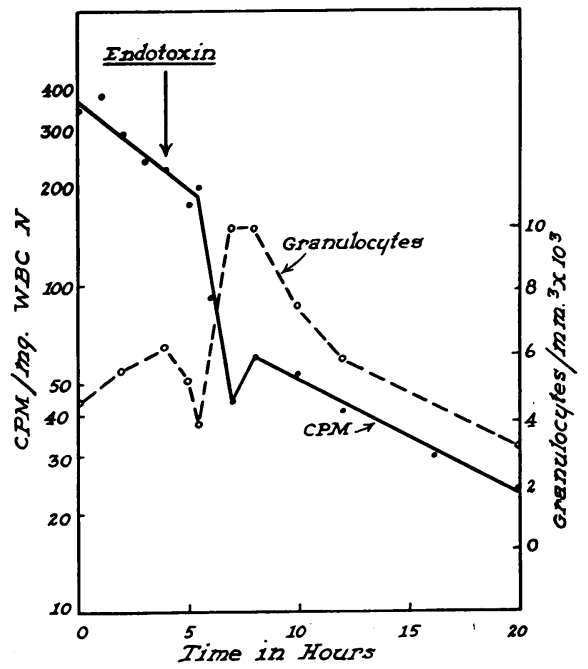

Fig. 2. INFLUENCE OF BACTERIAL ENDOTOXIN ON THE GRANULOCYTE DISAPPEARANCE CURVE AND ON THE CONCENTRATION OF GRANULOCYTES IN THE CiRCUlation. Bacterial endotoxin, $0.1 \mu \mathrm{g}$, was injected intravenously 4 hours after the infusion of labeled blood. A mild, transient granulocytopenia occurred, reaching a maximum 1.5 hours after the endotoxin was given. During the granulocytopenic phase the specific activity $(\mathrm{cpm} / \mathrm{mg}$ WBC N) did not change. As the concentration of granulocytes in the CGP increased, the specific activity of the granulocytes decreased sharply, indicating that unlabeled cells were entering the pool. Thereafter, the slope of the disappearance curve was altered as compared with the slope of the curve prior to the administration of endotoxin.

endotoxin and 1.5 and 5.0 hours after endotoxin was given. On each occasion the blood was labeled with $0.1 \mu \mathrm{g}$ of $\mathrm{DFP}^{32}$ per $\mathrm{ml}$ of whole blood. The results are presented in Table $\mathrm{V}$.

A transient granulocytopenia was detected in two of the six subjects 1.5 hours after endotoxin was given. In these two subjects there was a shift of granulocytes from the CGP to the MGP, without an increase in the TBGP at this time. In the other four subjects, there was an appreciable increase in the TBGP 1.5 hours after endotoxin. This increase was due primarily to an increase in MGP.

Five hours after endotoxin administration, both the CGP and the MGP were greatly increased but the ratio of the size of the CGP to the MGP was unaltered as compared with the values prior to the administration of endotoxin.

The influence of endotoxin on the granulocyte disappearance curve was studied in three subjects.
Four hours after an infusion of autogenous, DFP'-labeled blood, at which time the slope of the disappearance curve was established, each subject was given $0.1 \mu \mathrm{g}$ of endotoxin intravenously. The results in one subject with a transient early granulocytopenia are presented in Figure 2.

During the transient granulocytopenic phase which appeared 1.5 hours after endotoxin administration, the rate of decrease in the specific activity of the granulocytes in the circulation was unaltered. This would be expected since removal of granulocytes from the CGP would not alter the specific activity of the cells remaining. On the other hand, during the phase when the granulocyte count was increasing, there was a precipitous decline in the specific activity of the granulocytes in the CGP. Thus, during this period unlabeled granulocytes were entering this compartment diluting the specific activity of the cells.

\section{DISCUSSION}

In the physiological steady state, the GTR is equivalent to the rate of production of granulocytes by the bone marrow and the rate of utilization of granulocytes by the tissues. The study of production and destruction rates in patients with disorders of granulopoiesis should be of considerable interest and should add to our understanding of the pathophysiology of these diseases, just as a study of red cell production and destruction rates has added to our understanding of the pathophysiology of the anemias.

Direct quantitative measurement of the GTR has not been possible heretofore. Our studies indicate that normal subjects produce and utilize (destroy) $180 \times 10^{7}$ granulocytes per day per $\mathrm{kg}$ of body weight. This value is of the same order of magnitude as the value of $123 \times 10^{7}$ cells which Killmann, Cronkite, Fliedner and Bond (9) calculated from the observed ratio between mitoses in the erythroid and myeloid series, assuming an equal mitotic time for the two series.

The range of values for the GTR which we have obtained in normal subjects is wide. This probably is due in part to cumulative errors in the methods and in part to physiological variations. The GTR was reproducible in a given subject within a factor of two. The variation observed when the measurements were repeated in the 
same subject 1 month later could have been due to inaccuracies of the method, to physiological variations, or to both. Since it is well known that the leukocyte count varies in a subject from hour to hour and from day to day, it would be expected that the GTR would vary to a greater degree than the erythrocyte turnover rate. Our experiments do indicate that the variation in the GTR in a given subject from time to time is nearly as great as the differences which are observed beween individuals. Comparisons between the mean value of. at least four determinations would seem to be required before conclusions can be drawn reliably. The difference between the mean values for the GTR repeated in four subjects was 10 per cent.

In addition to the possible sources of error in the estimation of the blood pools and $T_{\frac{1}{2}}$ which were discussed previously $(1,2,5)$, the assumption is made in the calculation of the GTR that granulocytes do not return from the tissues to the TBGP. Several observers $(10,11)$ have assumed that there is an appreciable exchange of granulocytes between blood and tissues. However, experimental support for the existence of this exchange was not obtained by Craddock, Perry, Ventzke and Lawrence (8) or by Patt, Maloney and Jackson (12). From our own studies an appreciable return from tissues would seem unlikely, since the curve of disappearance of labeled cells from blood is a single exponential which decreases to background counting rates (1). If labeled granulocytes returned from the tissues to the blood, it would be expected that an equilibrium level would be approached. However, it should be pointed out that failure to observe such an equilibrium does not exclude the possibility that there is some exchange of granulocytes between these two pools. If the size of the tissue pool is sufficiently large by comparison with the TBGP, then a small return of granulocytes to the circulation may not have been detected. The lower limit of the size of a tissue pool of granulocytes which could exist and be compatible with our observations has been defined elsewhere (13).

In the present investigation perturbations were induced in the system with physical exercise, epinephrine, prednisone and bacterial endotoxin (Figure 3 ). From these studies certain characteristics of the system can be defined.

Exercise and epinephrine, as reported previously
(2), do not alter the size of the TBGP but cause a shift in cells from the MGP to the CGP. This shift of cells has no influence on the rate of disappearance of cells from the TBGP or on the GTR. This is further evidence that these two blood pools can be considered as one pool kinetically. Prednisone, on the other hand, increased the size of both the CGP and the MGP. The $\mathrm{T}_{\frac{1}{2}}$ was prolonged and the GTR was unaltered. Whether the TBGP was increased by mobilizing cells from the bone marrow or by prolonging the rate of removal of cells from the TBGP is not apparent from our studies. It can be stated that the rate of production and utilization of granulocytes at the new equilibrium level was not increased since the GTR was unaltered.

The alterations following administration of endotoxin differed from those with prednisone, physical exercise and epinephrine. Endotoxin produced two effects, namely, a shift of granulocytes from the CGP into the MGP and an influx of cells into the TBGP. In two of the six subjects margination preceded the influx of cells into the TBGP, and a transient neutropenia, that is, decrease in the size of the CGP, occurred. In the

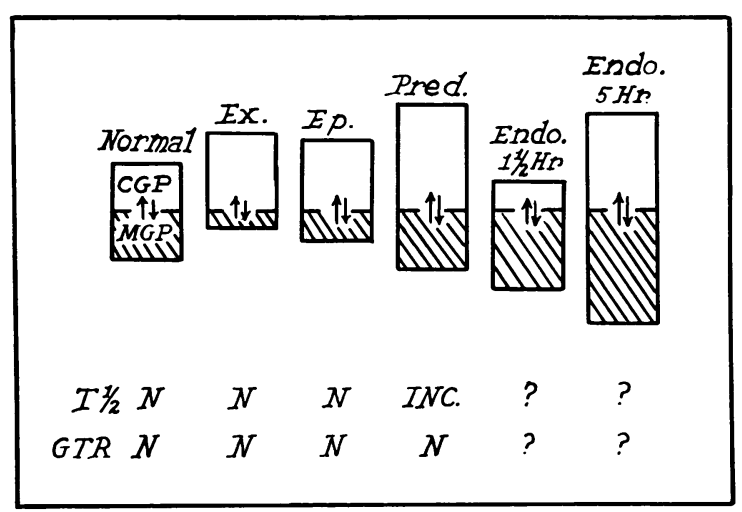

Fig. 3. Schematic summary of the influence of exercise (Ex.), epinephrine (Ep.), prednisone (Pred.) AND BaCterial ENDOTOXIN (ENDO.) ON THE CIRCUlatiNG GRANULOCYTE POOL, MARGINAL GRANULOCYTE POOL, HALFtIME DisAPPEARANCE RATE, (IN hOURS), AND GRANUloCYTE TURNOVER RATE $\times 10^{7}$ CELLS/KG/DAY. The total areas of the rectangles represent the relative sizes of the TBGP. The CGP is represented by the open area, the MGP by the hatched area. The relative values for the pool sizes for the two subjects with neutropenia 1.5 hours after the administration of endotoxin are given and are compared with those of all subjects 5.0 hours after endotoxin administration $(\mathrm{N}=$ normal, Inc. $=$ increased. $)$ 
other four subjects margination and mobilization of cells into the TBGP occurred simultaneously. Although the ratio of the CGP to MGP was decreased, there was no reduction in the size of the CGP and, therefore, no neutropenia. Five hours after endotoxin administration, the CGP as well as the MGP was greatly increased in all six subjects. Since granulocytes presumably do not move from the tissues to the blood, the unlabeled cells which entered the TBGP must have been released from the bone marrow pool of granulocytes. Craddock and co-workers (8) have presented other evidence that this is the case and they have suggested that the administration of endotoxin may be a useful procedure in assessing marrow granulocyte reserve. It would be interesting to know if endotoxin increased the GTR. Because the size of the TBGP was constantly changing after endotoxin was given, the system was not in a steady state and this calculation could not be considered accurate under these conditions.

The GTR is probably influenced by a wide variety of physiological and pathological factors. It is to be regretted that our studies in normal subjects have been limited to males. We have not felt justified in exposing normal females in the childbearing period of life to even these small amounts of radiation. Diurnal variations, psychological stress, variation with age, and the influence of meals on the GTR deserve study.

\section{SUMMARY}

1. The granulocyte turnover rate (GTR) has been determined in 45 normal male subjects. The size of the total blood granulocyte pool (TBGP), circulating granulocyte pool (CGP) and marginal granulocyte pool (MGP) has been measured in 70 normal male subjects. Perturbations were produced in the system with prednisone, physical exercise, epinephrine and bacterial endotoxin, and the influence of these perturbations on the above parameters was studied.

2 . The mean values $\pm 1 \mathrm{SD}$, expressed as number of cells $\times 10^{7}$ per kilogram of body weight were as follows: TBGP, $65.0 \pm 22.4$; CGP, 31.7 \pm 11.1 ; MGP, $33.3 \pm 16.0$. The mean value for the half-time disappearance rate $\left(\mathrm{T}_{\frac{1}{2}}\right)$ was $6.6 \pm$ 1.16 hours, and for the GTR, $179.9 \pm 74.3 \times$ $10^{7}$ granulocytes per $\mathrm{kg}$ of body weight per day.
3. Prednisone increased the size of the CGP, the MGP and the $T_{1}$. The GTR was not altered.

4. Physical exercise and epinephrine produced a shift of cells from the MGP to the CGP. The size of the TBGP, the $T_{\frac{1}{2}}$ and the GTR was not influenced.

5. Bacterial endotoxin produced a shift of cells from the CGP to the MGP and an influx of cells into the TBGP from the intramedullary pool of granulocytes.

\section{ACKNOWLEDGMENTS}

The cooperation of Dr. William Knott and Warden John Turner of the Utah State Prison is very much appreciated. We are also grateful to those inmates of the Utah State Prison who volunteered for these studies. Mrs. Roseann Moore, Mrs. Joyce Rose and Miss Doris Kurth provided valuable technical assistance. We are grateful to Dr. M. H. Kuizenga, Upjohn Co., Kalamazoo, Mich., for the supplies of heparin sodium; to Dr. D. M. Monroe, Dow Corning, Corp., Los Angeles, Calif., for the silicone 4141 ; to Dr. G. M. Karus, Film Dept., E. I. DuPont de Nemours and Co., Wilmington, Del., for the Mylar; to Dr. J. H. Brewer, Hynson, Westcott and Dunning, Baltimore, Md., for the supply of crude cobra venom; and to Dr. Fred H. Schultz, Jr., The Wander Co., Chicago, Ill., for the bacterial endotoxin (Lipexal, SA 1064).

\section{REFERENCES}

1. Mauer, A. M., Athens, J. W., Ashenbrucker, H., Cartwright, G. E., and Wintrobe, M. M. Leukokinetic studies. II. A method for labeling granulocytes in vitro with radioactive diisopropylfuorophosphate $\left(\mathrm{DFP}^{32}\right)$. J. clin. Invest. 1960, 39, 1481.

2. Athens, J. W., Raab, S. O., Haab, O. P., Mauer, A. M., Ashenbrucker, H., Cartwright, G. E., and Wintrobe, M. M. Leukokinetic studies. III. The distribution of granulocytes in the blood of normal subjects. J. clin. Invest. 1961, 40, 159.

3. Athens, J. W., Mauer, A. M., Raab, S. O., Haab, O. P., and Cartwright, G. E. Studies of granulocyte kinetics (abstract). J. clin. Invest. 1960, 39, 969.

4. Raab, S. O., Haab, O. P., Athens, J. W., Ashenbrucker, H., and Cartwright, G. E. Endotoxin induced alterations in granulocyte kinetics. Clin. Res. 1961, 9, 95.

5. Athens, J. W., Mauer, A. M., Ashenbrucker, H., Cartwright, G. E., and Wintrobe, M. M. Leukokinetic studies. I. A method for labeling leukocytes with diisopropylfluorophosphate $\left(\mathrm{DFP}^{32}\right)$. Blood 1959, 14, 303.

6. Comar, C. L. Radioisotopes in Biology and Agriculture, Principles and Practice. New York, McGraw-Hill, 1955, p. 18. 
7. Marsh, D. J., and Neale, E. A colorimetric method for the detection and determination of certain acid halide and acid anhydride compounds. Chem. and Ind. 1956, 22, 494.

8. Craddock, C. G., Jr., Perry, S., Ventzke, L. E., and Lawrence, J. S. Evaluation of marrow granulocytic reserves in normal and disease states. Blood $1960,15,840$.

9. Killmann, S. A., Cronkite, E. P., Fliedner, T. M., and Bond, V. P. Erythro- and granulocytopoietic turnover in human bone marrow estimated from mitotic indices. Blood. In press.

10. Osgood, E. E. Control of peripheral concentration of leukocytes in Homeostatic Mechanisms. Brook- haven Symposia in Biology, no. 10. Washington, D. C., Dept. of Commerce, 1957, p. 31.

11. Patt, H. M., and Maloney, M. A. Control of granulocyte formation. Ibid., p. 75.

12. Patt, H. M., Maloney, M. A., and Jackson, E. M. Recovery of blood neutrophils after acute peripheral depletion. Amer. J. Physiol. 1957, 188, 585.

13. Mauer, A. M., Athens, J. W., Warner, H. R., Ashenbrucker, H., Cartwright, G. E., and Wintrobe, M. M. An analysis of leukocyte radioactivity curves obtained with radioactive diisopropylfluorophosphate $\left(\mathrm{DFP}^{32}\right)$ in The Kinetics of Cellular Proliferation, F. Stohlman, Jr., Ed. New York and London, Grune and Stratton, 1959, p. 231. 